\title{
KCNQ1 wt Allele
}

National Cancer Institute

\section{Source}

National Cancer Institute. KCNQ1 wt Allele. NCI Thesaurus. Code C75623.

Human KCNQ1 wild-type allele is located in the vicinity of 11p15.5 and is approximately $404 \mathrm{~kb}$ in length. This allele, which encodes potassium voltage-gated channel subfamily KQT member 1 protein, plays a role in the regulation of both cardiac repolarization and potassium transport. Mutations in the gene are associated with hereditary long QT syndrome, Romano-Ward syndrome, Jervell and Lange-Nielsen syndrome and familial atrial fibrillation. 